DOI: https://doi.org/10.32839/2304-5809/2020-12-88-59

УДК 159.922

Чайковський Р.В.

Хмельницький інститут соціальних технологій Університету «Україна»

\title{
ВПЛИВ СІМЕЙНОГО ВИХОВАННЯ НА РОЗВИТОК ХАРАКТЕРУ ПІДЛІТКА
}

\begin{abstract}
Анотація. У статті викладено результати теоретичного аналізу впливу сімейного виховання на таку властивість особистості підлітка як характер. Визначено, що саме сім'я $е$ основою для формування та розвитку основних рис характеру дитини. Досліджено, що підлітковий вік є сензитивним та вирішальним для становлення особистості, і саме у підлітковому віці відбуваеться загострення рис характеру - акцентуація. Узагальнено психолого-педагогічні дослідження щодо впливу типу сімейного виховання та сімейного середовища. Виявлено, що характер формуеться під впливом зовнішнього середовища, соціуму, виховання. Висвітлено основні несприятливі умови біологічного та сощіального походження, що можуть сприяти формуванню патологічних варіантів характеру. Названо групи чинників, які сприяють розвитку патохарактерологічних особливостей. Розглянуто вплив неправильного сімейного виховання на появу вкрай несприятливих наслідків в характері дитини.
\end{abstract}

Ключові слова: сім'я, сімейне виховання, сімейне середовище, характер, акцентуація, патологічні варіанти характеру, підліток.

Chaikovskyi Rostyslav

Khmelnytskyi Institute of Social Technologies of University «Ukraine»

\section{THE IMPACT OF FAMILY UPBRINGING ON THE DEVELOPMENT OF CHARACTER OF A TEENAGER}

Summary. The results of theoretical analysis of impact of family upbringing on such peculiarity of personality of a teenager as character are described in this article. It is determined that the family itself is the basis for the formation and development the main traits of character of a child. It is researched, that teenage is sensitive and decisive for the formation of personality and in teenage the exacerbation of traits of character - accentuation takes place.Psycho-pedagogical researches connected with the impact of type of family upbringing and family environment, connected with the impact of different aspects of interfamily interaction on the formation of personality of a child, with the influence of wrong family upbringing on the appearance of unfavorable consequences in the character of a child are generalized. The changes in the character of children and teenagers in dependence from the character of parents' family are studied. It is generalized that a person's success in life and interaction with the world around him is greatly influenced by his character. It is revealed that the character is formed under the influence of the external environment, society, upbringing and can change under the influence of the life situation, volitional efforts aimed at achieving new goals. It is analyzed that all the positive and negative traits inherent in the personality are formed mainly under the influence of family and upbringing in childhood. It is found out that the character is formed under the influence of external environment, socium and upbringing. It is researched, that character is formed during human life, and, in its turn, the character itself influences on the development of personality in the whole. Main unfavorable conditions of biological and social origin, which can promote the formation of pathologic variants of character, are highlighted.The group of factors promoting the development of pathocharacterological peculiarities are named: genetic, organic, psychosocial. The impact of wrong family upbringing on the appearance of very unfavorable consequences in the character of a child is considered. Types of improper upbringing that contribute to the formation of personality disorders include indulgent hypoprotection, dominant hyperprotection, upbringing in the cult of disease, emotional rejection, increased moral responsibility, contradictory upbringing, upbringing outside the family. The influence of the following factors on the formation of the child's character: interpersonal relations in the family, stability of the family environment, "quality" of the family, its educational ability, the effectiveness of the educational environment, involvement of adolescents in various activities, adolescent self-esteem.

Keywords: family, family upbringing, family environment, character, accentuation, pathologic variants of character, teenager.

Постановка проблеми. Сімейне виховання є підгрунтям для формування та розвитку основних рис характеру дитини. Адже саме в сім’ї розпочинається особистісний розвиток дитини. Особливо важливим сімейне виховання $є$ для підлітків, що потребують особливої уваги з боку батьків. Саме цей віковий період є сензитивним та вирішальним для становлення і закріплення образу «Я». Слід також і врахувати те, що саме у підлітковому віці відбувається загострення рис характеру - акцентуація. Враховуючи вище сказане, встановлено, що дана проблема потребуе детального вивчення та розкриття особливостей впливу сімейного виховання на розвиток характеру підлітка.
Аналіз останніх досліджень і публікацій. Питання впливу сімейного виховання на розвиток характеру підлітка неодноразово ставало предметом наукових досліджень. Так, у численних роботах вітчизняних і зарубіжних учених (Т. Алексеєнко, Ю. Азарова, Ф. Байкова, В. Гурова, Т. Кравченко, М. Міщенка, Т. Поніманської, Л. Пономаренко, В. Постового, А. Харчева, Т. Шеляг тощо) розглядаються найрізноманітніші аспекти цієї проблеми: від теоретичних проблем сім'ї до основ психолого-педагогічної культури батьків та умов ефективного сімейно-родинного виховання. Важливим науковим доробком $є$ праця I. Вороніна, в якій він здійснив аналіз впли- 
ву різних аспектів внутрісімейної взаємодії на формування особистості дитини [2, с. 65]. В свою чергу А. Лічко докладно розглядає вплив неправильного сімейного виховання на появу вкрай несприятливих наслідків в характері дитини [7]. Одним з перших авторів, хто докладно описали зв'язок виникнення патохарактерологічного розвитку з сімейною обстановкою була В. Гур'єва [4]. Г. Сухарєвою [10] детально вивчені типи змін характеру дітей і підлітків в залежності від характеру батьківської сім'ї.

Виділення невирішених раніше частин загальної проблеми. Залишається не вирішеним питання особливостей протікання процесу впливу сімейного виховання на розвиток характеру підлітка.

Формулювання цілей статті. Метою статі $€$ висвітлення проблемного питання впливу сімейного виховання на розвиток характеру підлітка.

Виклад основного матеріалу дослідження. 3 моменту народження і до самої смерті людина формуе і розвиває особливі риси своєї особистості. Кожна дитина після появи на світ вже володіє індивідуальним типом темпераменту. Так, I. Павлов виділяв чотири основні типи нервової системи, які відрізняють людей один від одного за характером протікання процесів збудження і гальмування. На успішність людини в житті і взаємодії з навколишнім світом в значній мірі впливає й її характер.

Аналізуючи психолого-педагогічну літературу виявлено, що характер фрормуеться під впливом зовнішнього середовища, сощіуму, виховання. Це такі стійкі властивості конкретної особистості, які визначають спосіб взаємодії з оточуючими і реагування на ті чи інші ситуащії. Під рисами характеру розуміють ті особливості, які відрізняють конкретного індивідуума.

Характер людини може змінюватися під впливом зовнішніх умов, життевої ситуації, вольових зусиль, спрямованих на досягнення нових цілей. В даний час більшість вчених визнає, що всі позитивні і негативні риси, закладені в особистості, формуються, головним чином, під впливом сім'ї та виховання в дитинстві [2].

Сімейне виховання має величезне значення у вихованні, освіті і становленні особистості. Сім'я виступає домінуючим інститутом у форомуванні особистості дитини. Причому тільки та сім'я має позитивний вплив, яка допомагає дитині відчувати себе рівноправним членом сімейного колективу, де їі люблять; вона має у сім'ї права і обов'язки; до іï потреб ставляться з розумінням.

Саме в родині закладаються основи моральності людини, формуються норми поведінки, розкриваються внутрішній світ і індивідуальні якості особистості. Крім цілеспрямованого батьківського виховання на дитину впливає внутрішньосімейна атмосфрерна загалом, причому ефрект цього впливу проявляється з віком, відбиваючись у структурні особистості. Особливо актуальним це $є$ для підлітків, адже саме в підлітковому віці батьківське ставлення набуває вирішального значення для становлення і закріплення образу «Я». Цей образ і ставлення до себе фрормуються під впливом того образу, що склався в батьків. Тому в сучасних умовах України саме сім'ї надаеться пріоритетне значення.
У підлітковому віщі відбувається загострення рис характеру. Прагнення до самостійності, усвідомлення свого фрізичного і духовного змужніння - одна 3 найбільш яскравих рис цього віку. I якщо батькам вдасться перебудувати свої відносини 3 підростаючими дітьми і змінити стиль виховання, то це, в свою чергу, відіб'ється і на характерні дитини. При більшій виразності деякі риси характерну накладають відбиток на особистість як таку i, нарешті, можуть набувати патологічний характер, руйнуючи структурну особистості. Важливим є дослідження того, який стиль виховання переважає в сім'ї і який вплив він робить на форомування особистості у підлітків [5; 8].

Відомо, що сім'я має значний вплив на розвиток психіки дитини; цей фракт не викликає сумнівів, однак механізми цього впливу ще поки остаточно не з'ясовані. 3 перших днів життя дитини соціальне середовище постає перед нею як система сімейної взаємодії. Батьки дитини є спочатку єдиними носіями соціальних стосунків і єдиною опосередкованою ланкою, яка пов'язує дитину зі світом.

Фізіологічною основою характеру, що складається 3 генотипу та фенотипу, є загальний і людський тип вищої нервової діяльності та утворення динамічних стереотипів. Характер фрормується протягом життя людини i, в свою чергу, сам впливає на розвиток особистості в цілому. Іноді ряд несприятливих умов біологічного та соціального походження може сприяти формуванню патологічних варіантів характеру.

Патохарактерологічні реакції е психогенними особистісними реакціями. Ці реакції відрізняють від "характерологічних» - непатологічних порушень поведінки, які проявляються тільки в певних ситуащіях, не ведуть до дезадаптації особистості і не супроводжуються сомато-вегетативними порушеннями. Патологічні ситуаційні (патохарактерологічні) реакції частіше розвиваються поступово, на основі психологічних.

У сучасній клінічній психології виділяють три групи чинників, які сприяють розвитку патохарактерологічних особливостей:

- генетичні;

- органічні;

- психосоціальні [7].

А. Лічко детально розглядає вплив неправильного сімейного виховання на появу вкрай несприятливих наслідків в характері дитини [7, с. 102]. Гіпопротекція характеризуеться відсутністю інтересу до потреб і емоційного життя дитини, невключеністю в процес його розвитку, бездоглядністю. Найчастіше гіпопротекція носить прихований характер, коли батьки виявляють увагу до потреб дитини лише фрормально, обмежуючись задоволенням його базових потреб в їжі, крові та одязі, але не цікавлячись ні духовним світом, ні колом спілкування, ні захопленнями. $\mathrm{У}$ наш час батьки все частіше намагаються замінити живе спілкування гаджетами, які дозволяють не займатися 3 дитиною і не витрачати на нього час. Така батьківська помилка часто призводить до розвитку неробства, істеричності, безвідповідальності дитини. Часто подібний тип виховання поєднуеться 3 прагненням батьків будь-що-будь виправдати вчинки чада в очах суспільства, прагненням уникнути навіть заслуженого покарання. Нескладно припустити, 
що подібне батьківське потурання призводить до відчуття власної безкарності і нерозумінню допустимих меж. За цим слід асоціальна поведінка, яке складно піддається корекції. Не отримуючи достатнього тепла і ласки від домочадщів, дитина схильна йти в себе, проявляти мрійливість.

Гіперпротекція проявляеться в дріб'язковому контролі за будь-якими вчинками дитини, надмірною опікою, забороною на самостійні дії і рішення. Постійне стеження, сувора система заборон i покарань, відсутність можливості до отримання власного життевого досвіду створюють небезпечну ситуацію, коли в характері дитини з'являються риси несамостійності, індрантильності, нерішучості, боязні постояти за себе. Крім того, дитина рано чи пізно, починае бунтувати проти постійних заборон, підкоряючись своїй природній допитливості. В крайніх своїх проявах такий бунт може привести до повної відмови від батьківської турботи, догляду з дому, асоціальної поведінки [2, с. 66].

Важливість міжособистісних стосунків особистості у сім'ї як малій психосоціальній групі та їх вплив на становлення характеру дитини в тому, що значущий соціально-психологічний чинник емощійної врівноваженості і психічного здоров'я - стабільність сімейного середовища.

Велике значення має «якість» сім'ї, її виховна здатність. Сім'я, нездатна виховувати, приводить до порушень в процесі соціалізації школяра ще з самого початку. Якщо у дітей погані відносини 3 одним або обома батьками, якщо вони не відчувають батьківської підтримки, то вони, можливо, виявляться втягнутими у злочинну діяльність; такі діти, ймовірно, поводитимуться агресивно по відношенню до своїх батьків. Для формування «Я» дитини вирішальним соціальнопсихологічний чинником $є$ погляди і поведінка батьків. Завдяки їх правильній позиції школяр створює про себе певну думку, фрормує самооцінку. При суворій позиції особистість відчувае страх i оцінюе себе негативно. Виникнення у дітей різних порушень в поведінці i самооцінці, пов'язаних 3 сімейним середовищем, свідчить про зниження виховної функщії батьківської сім'ї як малої психосоціальної групи [1, с. 118].

Відомо, що сім'я як мала психосоціальна група $є$ якнайкращим виховним середовищем для особистості. Проте деякі соціально-психологічні чинники, пов'язані зі складом сім'ї, станом її внутрішніх взаємин або виховально- невірними позиціями батьків, можуть викликати зниження виховної здатності сім'ї. Ці соціальнопсихологічні чинники можуть приводити до порушень в поведінщі дітей i навіть до негативних явищ у формуванні їхнього характеру. Одним з соціально-психологічних чинників, що порушують виконання виховних фрункцій сім'ї, можуть бути зміни в її складі [6, с. 54].

Стабільність сімейного середовища є важливим сощіально-психологічним чинником для емощійної рівноваги і психічного здоров'я особистості дитини. Розпад сім'ї як малої психосощіальної групи, викликаний розлученням або окремим мешканням батьків, завжди приносить потрясіння і залишає у дитини міцну образу, яку можна лише пом'якшити. Розлука з одним з батьків може привести до появи у дитини відчуття страху, депресію i ряд інших симптомів неврозу, заниженої самооцінки загалом [3, с. 19].

Від того, наскільки ефективно організована виховне середовище, залежить формування базових особливостей особистості і подальша доля підлітка. Виховне середовище включає себе всі способи догляду за дитиною і його розвитку, починаючи від засобів гігієни і закінчуючи іграшками, навчальними матеріалами. Будь-яка життева ситуація, починаючи від великої покупки i закінчуючи днем народження родича, може стати педагогічно значущою і дати поштовх до розвитку як позитивних, так і негативних рис характеру.

Передача накопичених знань, вплив на поведінку дитини та її особливості здійснюеться за допомогою спілкування 3 дорослими. Зчитуючи емоції батьків, дитина вчиться оцінювати ту чи іншу життеву ситуацію, а спостерігаючи різні моделі поведінки, вибирає способи реагування та взаємодії з соціумом.

Сім'я долучає дитину до різних видів діяльності, таким як гра, спілкування, пізнавальна, навчальна, трудова, предметна. Без розвитку відповідних навичок і умінь дитина не зможе повноцінно і успішно жити в суспільстві. Основною помилкою старших членів сім'ї в процесі навчання дитини відповідним його віком навичкам $€$ прагнення робити за нього ту роботу, з якою він вже справляється самостійно. Це, у свою чергу, призводить до розвитку таких негативних рис характеру, як інфантилізм і нерішучість. Якщо цілеспрямовано допомагати дитині стати самостійніше, заохочувати кожну спробу вивчити властивості предметів і оволодіти новими навичками, в майбутньому у нього розвинуться цілеспрямованість, посидючість і самоконтроль. Крім сприятливого середовища для формування навички і розвитку характеру в цілому, необхідно цілеспрямоване позитивне підкріплення, яке створюе у дитини відчуття успіху.

Ми підтримуємо думку I. Вороніна, що для правильного формування характеру дитини необхідно, щоб його самооцінка була адекватна. Це можливо тільки в умовах його безумовного прийняття і любові від близьких людей. Любов батьків є базою для розвитку співчуття, чуйності і чуйності по відношенню до інших людей. А адекватна самооцінка дозволяе людині дати характеристику своїм рис характеру і випробовуваним емоціям, закладає основу для самоконтролю поведінки і вчинків [2, с. 67].

Висновки 3 даного дослідження i перспективи подальшого розвитку в цьому напрямку. Таким чином, саме сім'я постае для дитина тим началом, яке допомагає створювати початкове уявлення про те, як будуються взаємини в світі, отримуе знання про навколишню дійсність, набуває необхідні для життя якості характеру. Встановлено, що формування позитивних чи негативних рис характеру залежить від виховного середовища. Якщо це середовище позитивне, мирне і в сім'ї панує взаєморозуміння, якщо батьки піклуються один про одного і вчать цьому дитину, якщо приділяеться достатньо уваги її культурному розвитку, вдосконаленню навичок, взаємодії з однолітками, духовному світу, підліток виростає гармонійною особистістю 
3 необхідними позитивними рисами характеру успішної людини.

Проведене дослідження не вичерпуе всіх аспектів зазначеної проблеми. Залишаеться не вивче- ним яким чином розвивається характер у підлітків у неповних сім'ях; у сім'ях, які потрапили у складні життеві труднощі; у сім'ях де проживає старше покоління - бабусі, дідусі; у багатодітних сім'ях тощо.

\section{Список літератури:}

1. Алексеенко Т.Ф. Виховний потенціал сім'ї в сучасних умовах. Украӥнський соціул. Київ, 2008. С. 63-67.

2. Воронин И.В. Влияние семьи на формирование характера ребёнка. Педагогика: традиции и инновации : материаль Х Междунар. науч. конфб. (г. Казань, декабрь 2018 г.). Казань : Молодой ученый, 2018. С. 65-68. URL: https://moluch.ru/conf/ped/archive/316/14687/ (дата звернення: 21.12.2020).

3. Гаміна Т.С., Гончар О.Ю. Педагогіка сімейного виховання : Навчальний посібник. Луганськ : Альма-матер, $2012.523 \mathrm{c}$.

4. Гурьева В.А., Гиндикин В.Я. Социальное сиротство - причина и результат психической аномальности девиаций личности и поведения. Сироты России: проблемы, надежды, будущее. Москва, 1994. С. 53-54.

5. Ігнатов O.M. Акцентуації особистості як фактор детермінації протиправної поведінки. Науковий вісник Міжнародного гуманітарного університету. 2013. Вип. 6-3(2). С. 76-79.

6. Кон И.С. Родители и дети. Психология ранней юности. Москва : Просвещение, 1989. 255 с.

7. Личко А.Е. Психопатии и акцентуации характера у подростков. Москва : Речь, 2010. 256 с.

8. Савчин М.В., Василенко Л.П. Вікова психологія : навчальний посібник. Київ : Академвидав, 2005.360 с.

9. Сухарева Г.Е. Лекции по психиатрии детского возраста. Москва : Медицина, 1974. 320 с.

10. Таранова Е.И. Семья как фрактор, влияющий на формирование аутоагрессивного, суицидального поведения в подростковом возрасте. Научныєе ведомости. 2011. № 10(105). Выпуск 14. С. 44-50.

\section{References:}

1. Alyeksyeyenko T.F. (2008) Vykhovnyi potentsial simii v suchasnykh umovakh [The educational potential of the family in modern conditions]. Ukrainskyi sotsium, pp. 63-67.

2. Voronin I.V. (2018) Vlijanie sem'i na formirovanie haraktera rebjonka [The influence of the family on the formation of the character of the child]. Pedagogika: tradicii $i$ innovacii: materialy X Mezhdunarodnoj nauchnoj konferencii (Rossia, Kazan', dekabr' 2018 ). Kazan': Molodoj uchenyj, pp. 65-68.

3. Hamina T.S., Honchar O.Yu. (2012) Pedahohika simeinoho vykhovannia: Navchalnyi posibnyk [Pedagogy of family education]. Luhansk: Alma-mater. (in Ukrainian)

4. Gur'eva V.A., Gindikin V.Ja. (1994) Social'noe sirotstvo - prichina i rezul'tat psihicheskoj anomal'nosti deviacij lichnosti i povedenija [Social orphanhood is the cause and result of mental abnormality of personality and behavior deviations]. Siroty Rossii: problemy, nadezhdy, budushhee, pp. 53-54.

5. Ihnatov O.M. (2013) Aktsentuatsii osobystosti yak faktor determinatsii protypravnoi povedinky [Accentuations of personality as a factor in determining illegal behavior]. Naukovyi visnyk Mizhnarodnoho humanitarnoho universytetu, vol. 6-3(2), pp. 76-79.

6. Kon I.S. (1989) Roditeli i deti. Psihologija rannej junosti [Parents and children. Psychology of early adolescence]. Moskva: Prosveshhenie. (in Russian)

7. Lichko A.E. (2010) Psihopatii $i$ akcentuacii haraktera u podrostkov [Psychopathies and character accentuations in adolescents]. Moskva: Rech'. (in Russian)

8. Savchyn M.V., Vasylenko L.P. (2005) Vikova psykholohiia: navchalnyi posibnyk [Age psychology]. Kyiv: Akademvydav. (in Ukrainian)

9. Suhareva G.E. (1974) Lekcii po psihiatrii detskogo vozrasta [Child psychiatry lectures]. Moskva: Medicina. (in Russian)

10. Taranova E.I. (2011) Sem'ja kak faktor, vlijajushhij na formirovanie autoagressivnogo, suicidal'nogo povedenija $\mathrm{v}$ podrostkovom vozraste [Family as a factor influencing the formation of autoaggressive, suicidal behavior in adolescence]. Nauchnye vedomosti, vol. 14, no. 10(105), pp. 44-50. 